\title{
THE PSALTER AND MARTYROLOGY OF RICEMARCH.
}

The Psalter and Martyrology of Ricemarch (1914), edited for the Henry Bradshaw Society by Dr H. J. Lawlor, reproduces, in seventyeight collotype plates, the Hieronymian Martyrology and nine tables relating to Kalendar (pl. ii-lviii), selected pages of St Jerome's Latin Psalter secundum Hebraicam veritatem (pl. lix-lxxv), and the verses of Ricemarch on the Psalter (pl. lxxvi), all contained in the Trinity Coll. Dublin MS A 4. 20 ; and parts of two pages of the C. C. C. C. copy of St Augustine De Trinitate (pl. 1xxiii sq.), a product of the same school. The Trin. Coll. MS has been noticed and partially reproduced more than once before; and most notably it was described by Henry Bradshaw in his Collected Papers; P. Delehaye printed the text of the Martyrology in Analecta Bollandiana xxxii (November IgI3) while the present volumes were in the press; and Dr Lindsay treated of the palaeography of the MS in Early Welsh Script (I9I2). The plates occupy vol. ii : vol. i contains Dr Lawlor's Introduction; a reprint of the Martyrology and of the verses; a collation of the Psalter with Vallarsi's text, with reference also to Lagarde's text, and to other Latin Psalters; notes on the Martyrology, chiefly in the way of collation with the texts of the principal MSS, on the nine tables, and on the verses of Ricemarch; and lastly, an appendix containing 'The Lament of Ricemarch', ninety pathetic verses bewailing the 'frightfulness' of the Norman conquerors of south-west Wales in rog4, from the Brit. Mus. MS Cotton, Faustina C. I. The Dublin and Cambridge MSS are products of the 'School of St Davids'. Sulien the Wise was born in Cardiganshire $c .1014$, and went to Ireland c. $105^{8}$ to perfect his studies in the Irish schools, which, reviving with the slackening of the Danish invasions, had, just at this period, reached the zenith of their renewed life and of their new organization. Thirteen years later he returned to Wales and founded a school, probably at Llanbadarn Fawr; but, Sulien having become bishop of St Davids in $10^{72}$, it is commonly called the 'School of St Davids'. Sulien's principal disciples were his four sóns, of whom Ricemarch was one; and according to the chronicler, 'after Ricemarch instruction for scholars ceased at Menevia', apparently as a result of the Norman conquest. The studies and aptitudes of the school included patristic literature, hagiology, the writing of Latin verses, and calligraphy and illumination. All these are illustrated by the 
Dublin MS, which was written for Ricemarch by one Ithael, while John, Ricemarch's brother, added the illuminated capitals, and apparently Ricemarch himself wrote his curious verses on David and the Psalter. This is, put shortly, the story told by Dr Lawlor in the Introduction, where he has also some interesting pages on the Irish scholars and schools from the seventh century to the eleventh, and points out the signs of Irish influence on the school of St Davids both in the Martyrology and in Ricemarch's Life of St David (perhaps the first biography of David to be written, and certainly the source of all the later lives). In the Introduction Dr Lawlor also describes the MS and discusses its date and history : it was written approximately in ro79; and in the seventeenth century it belonged to William Bedell, Provost of Trinity Coll. and later Bishop of Kilmore, who bequeathed it to James Ussher, among whose books it passed to Trinity College in about r665. I do not know anything about the criticism of the Hieronymian Martyrology and can therefore form no judgement of Dr Lawlor's disçussion of Ricemarch's text; but he seems to succeed in shewing by means of Ricemarch that the Epternach text, for the superiority of the text of which Mgr Duchesne contends in his edition of the Martyro. logy (Acta SS. Nov. ii), is composite and not of equal authority throughout; and consequently that Mgr Duchesne's argument needs revision. As to the Psalter, Dr Lawlor points out that it supports Lagarde's text as against Vallarsi's, and is closely related to Lagarde's Reichenau and Bamberg MSS, both of the tenth century. I wonder why Dr Lawlor did not print the whole of the introduction to the Psalter, instead of only the selection on pp. xviii sq. With reference to the final note on $\mathbf{p .} \mathbf{1 2 0}$, is not the allusion, in the last line of Ricemarch's verses, to Ex. xxvi $\mathbf{r}$; and the meaning of the last two lines, 'may Ithael (ille), the scribe, have his name inscribed on the gems of the High-priest's breastplate; and the cherubim depicted on the curtains of the shrine take John (hunc), the painter, under the shelter of their wings', kinubin being in the genitive?

F. E. Brightman. 